\title{
Antidiabetic and Antioxidant Effects of Newly Synthesized Pyrimido[1,6-a] Pyrimidine Derivatives in Neonatal Streptozotocin-Induced Diabetic Rats
}

\section{Osama Mohamed Ahmed ${ }^{1 *}$, Ahmed M. Hussein ${ }^{2,3}$ and Rasha Rashad Ahmed ${ }^{4}$}

${ }^{1}$ Physiology Division, Zoology Department, Faculty of Science, Beni-Suef University, Egypt

${ }^{2}$ Organic Chemistry Division, Chemistry Department, Faculty of Science, Beni-Suef University, Egypt

${ }^{3}$ Chemistry Department, Faculty of Science, Al-Quaiyah, Shaqra University, KSA

${ }^{4}$ Cell biology, Histology and Genetics Division, Zoology Department, Faculty of Science, Beni-Suef University, Egypt

\begin{abstract}
Synthesis of some novel pyrimido[1,6- $a$ ]pyrimidine derivatives $\mathbf{4 , 8}$ and $\mathbf{1 0}$ was described through the respective reactions of sodium salts of formyl ketones 1,7 and 9 with 6-aminothiouracil. The characterization of the reaction products was confirmed by using the available elemental analysis and spectral data. One of these derivatives (4b), 1-thioxo-1,2,7,8,9,10-hexahydro-3H-pyrimido[1,6-a]quinazolin-3-one, was tested using sublethal dose level (10 mg/kg b. w./day for 3 weeks) and was found to have potent antihyperglycemic, antihyperlipidemic and antioxidant properties in neonatal streptozotocin-induced (n-STZ) diabetic male and female albino rats.
\end{abstract}

Keywords: Formyl salt; 6-aminothiouracil; $3 H$-pyrimido[1,6-a] pyrimidine; Neonatal streptozotocin-induced diabetic rats, Antidiabetic and antioxidant efficacies

\section{Introduction}

Pyrimidopyrimidines, analogues of folic acid (one of the $\mathrm{B}$ vitamins that is a key factor in the synthesis of nucleic acids RNA and DNA) and an important class of annulated uracil and thiouracil, are pharmacologically useful as powerful inhibitor of aggregation of thrombocytes [1], hepatoprotective [2], bronchodilators, anticancer [35], vasodilators [6,7], antiallergic [8] and antihypertensive [9] agents. It was also reported that pyrimidopyrimidine derivatives inhibited lipid peroxidation in human and rat liver [10]. Here, an easy construction of some new and interesting pyrimidopyimidines, the ring systems that can be found in marine-derived natural products such as crambescidin [11] and batzelladine [12] alkaloids has been achieved.

Due to the high prevalence of diabetes mellitus worldwide, extensive research is still being performed to develop new antidiabetic agents and determine the mechanisms of action. As type 2 diabetes mellitus (noninsulin dependent diabetes mellitus, NIDDM) is much more prevalent form of diabetes and is responsible for $90 \%$ of the disease prevalence [13-15], experimental animal model representing type 2 diabetes, neonatal streptozotocin diabetic rats, is used to assess the antidiabetic as well as the antioxidant efficacy of the tested compound. This animal model develops most of the biochemical and pathological symptoms associated with type 2 diabetes in humans [16].

There are many classes of antidiabetic agents available and these drugs have different mechanisms of action and variable efficacy. Most of these drugs have many side effects. Thus, the continuous search for novel antidiabetic agents that are more effective and safe is a target of research by many investigators. 3(H)-quinazolinone derivatives have been shown as a group of compounds of broad medical interest [17-21]. It was reported that some $3(H)$-quinazolinone derivatives exhibited potent antihyperlipidemic and antihyperglycemic activity in alloxan diabetic-hypercholesterolemic and streptozotocin diabetic rats respectively $[22,23]$.

Thus, this study was designed to synthesize new pyrimido[1,6- $a]$ pyrimidine derivatives and to assess the anthyperglycemic, antihyperlipidemic and antioxidant efficacies of one of these derivatives, 1-thioxo-1,2,7,8,9,10-hexahydro-3H-pyrimido[1,6-a] quinazolin-3one (4b) in neonatal streptozotocin-induced type 2 diabetes in rats.

\section{Materials and Methods}

\section{Chemistry}

All melting points were determined on an electrothermal apparatus and are uncorrected. IR spectra were recorded ( $\mathrm{KBr}$ discs) on a BRUKER IFS-25 FT-IR spectrophotometer at the region $400-4000 \mathrm{~cm}^{-1} .{ }^{1} \mathrm{H}$ NMR spectra were recorded in $\mathrm{CDCl}_{3}$ and $\left(\mathrm{CD}_{3}\right)_{2} \mathrm{SO}$ solutions on a Varian Gemini $300 \mathrm{MHz}$ spectrometer and chemical shifts are expressed in $\delta$ units using TMS as an internal reference. Mass spectra were recorded on a GC-MS QP 1000 EX Shimadzu. Elemental analyses were carried out at the Microanalytical Center of the Cairo University, Giza, Egypt. Piperidine acetate was prepared by addition of $5 \mathrm{~mL}$ piperidine to a mixture of $4 \mathrm{~mL}$ acetic acid and $10 \mathrm{~mL}$ water [24,25].

\section{Synthesis of cyclocondensed pyrimido[1,6-a]pyrimidine} derivatives (4a-d), (8) and (10)

General procedure: A mixture of equivalent amounts of sodium salts (1), (7) or (9) (0.012 mole) and 6-aminothiouracil was refluxed with a solution of piperidine acetate $(1.5 \mathrm{~mL})$ for $15-20$ minutes. The reaction mixture is then diluted with $20 \mathrm{~mL}$ ethanol and refluxed for another $1 \mathrm{hr}$. The reaction was quenched by the addition of $1.5 \mathrm{~mL}$ acetic acid, then the mixture was cooled and the solid product was collected by filtration and recrystallized from the appropriate solvent (Tables 1 and 2).

\section{Biology}

Experimental animals: Experimental albino mice (weighing 20-25 g) and pregnant female albino rats (weighing 180-200 g) were obtained from the Animal House of Ophthalmology Institute, Giza, Egypt. They kept under observation for 2 weeks in the department animal house

*Corresponding author: Osama Mohamed Ahmed, Zoology Departmen (Physiology Division), Faculty of Science, Beni-Suef University, Egypt; Tel: 0020101084893; Fax: 0020822334551; E-mail: osamamoha@yahoo.com

Received January 26, 2012; Accepted February 23, 2012; Published February 24,2012

Citation: Ahmed OM, Hussein AM, Ahmed RR (2012) Antidiabetic and Antioxidant Effects of Newly Synthesized Pyrimido[1,6-A]Pyrimidine Derivatives in Neonatal Streptozotocin-Induced Diabetic Rats. Med chem 2: 020-028. doi:10.4172/21610444.1000108

Copyright: (C) 2012 Ahmed OM, et al. This is an open-access article distributed under the terms of the Creative Commons Attribution License, which permits unrestricted use, distribution, and reproduction in any medium, provided the original author and source are credited. 
Citation: Ahmed OM, Hussein AM, Ahmed RR (2012) Antidiabetic and Antioxidant Effects of Newly Synthesized Pyrimido[1,6-A]Pyrimidine Derivatives in Neonatal Streptozotocin-Induced Diabetic Rats. Med chem 2: 020-028. doi:10.4172/2161-0444.1000108

Table 1: Characterization data of compounds $4 a-d, 8$ and 10

\begin{tabular}{|c|c|c|c|c|c|c|c|}
\hline \multirow{2}{*}{ Comp. No. } & \multirow{2}{*}{$\begin{array}{l}\text { M.P.OC } \\
\text { Solvent }\end{array}$} & \multirow{2}{*}{$\begin{array}{l}\text { Color } \\
\text { Yield\% }\end{array}$} & \multirow{2}{*}{$\begin{array}{l}\text { Mol. Formula } \\
\text { (M.Wt.) }\end{array}$} & \multicolumn{4}{|c|}{ Elemental analysis calc. / found\% } \\
\hline & & & & C & $\mathbf{H}$ & $\mathbf{N}$ & $\mathbf{S}$ \\
\hline $4 a$ & $\begin{array}{l}276-277 \\
\text { EtOH }\end{array}$ & $\begin{array}{l}\text { Pale brown } \\
71.6\end{array}$ & $\begin{array}{l}\mathrm{C}_{10} \mathrm{H}_{9} \mathrm{~N}_{3} \mathrm{OS} \\
(219)\end{array}$ & $\begin{array}{l}54.79 \\
54.88\end{array}$ & $\begin{array}{l}4.11 \\
4.22\end{array}$ & $\begin{array}{l}19.17 \\
19.00\end{array}$ & $\begin{array}{l}14.61 \\
14.60\end{array}$ \\
\hline $4 b$ & $\begin{array}{l}230-232 \\
\text { EtOH }\end{array}$ & $\begin{array}{l}\text { Yellow } \\
75.2\end{array}$ & $\begin{array}{l}\mathrm{C}_{11} \mathrm{H}_{11} \mathrm{~N}_{3} \mathrm{OS} \\
(233)\end{array}$ & $\begin{array}{l}56.65 \\
56.66\end{array}$ & $\begin{array}{l}4.72 \\
4.66\end{array}$ & $\begin{array}{l}18.02 \\
18.22\end{array}$ & $\begin{array}{l}13.73 \\
13.71\end{array}$ \\
\hline 4c & $\begin{array}{l}249-251 \\
\text { EtOH }\end{array}$ & $\begin{array}{l}\text { Yellow } \\
81\end{array}$ & $\begin{array}{l}\mathrm{C}_{13} \mathrm{H}_{15} \mathrm{~N}_{3} \mathrm{OS} \\
(261)\end{array}$ & $\begin{array}{l}59.77 \\
59.55\end{array}$ & $\begin{array}{l}5.74 \\
5.89\end{array}$ & $\begin{array}{l}16.09 \\
15.99\end{array}$ & $\begin{array}{l}12.26 \\
12.26\end{array}$ \\
\hline 4d & $\begin{array}{l}230-231 \\
\text { EtOH }\end{array}$ & $\begin{array}{l}\text { Yellow } \\
70.3\end{array}$ & $\begin{array}{l}\mathrm{C}_{17} \mathrm{H}_{23} \mathrm{~N}_{3} \mathrm{OS} \\
(317)\end{array}$ & $\begin{array}{l}64.35 \\
64.34\end{array}$ & $\begin{array}{l}7.25 \\
7.45\end{array}$ & $\begin{array}{l}13.24 \\
13.33\end{array}$ & $\begin{array}{l}10.09 \\
10.11\end{array}$ \\
\hline 8 & $\begin{array}{l}266-268 \\
\text { EtOH }\end{array}$ & $\begin{array}{l}\text { Pale yellow } \\
61.1\end{array}$ & $\begin{array}{l}\mathrm{C}_{8} \mathrm{H}_{7} \mathrm{~N}_{3} \mathrm{OS} \\
(193)\end{array}$ & $\begin{array}{l}49.74 \\
49.58\end{array}$ & $\begin{array}{l}3.63 \\
3.61\end{array}$ & $\begin{array}{l}21.76 \\
21.65\end{array}$ & $\begin{array}{l}16.58 \\
16.65\end{array}$ \\
\hline 10 & $\begin{array}{l}\text { 288-289 } \\
\text { EtOH/ DMF }\end{array}$ & Yellowish green 63 & $\begin{array}{l}\mathrm{C}_{13} \mathrm{H}_{9} \mathrm{~N}_{3} \mathrm{OS} \\
(255)\end{array}$ & $\begin{array}{l}61.17 \\
61.24\end{array}$ & $\begin{array}{l}3.53 \\
3.42\end{array}$ & $\begin{array}{l}16.47 \\
16.45\end{array}$ & $\begin{array}{l}12.55 \\
12.34\end{array}$ \\
\hline
\end{tabular}

Table 2: The spectral data of the newly synthesized compounds 4a-d, 8 and 10.

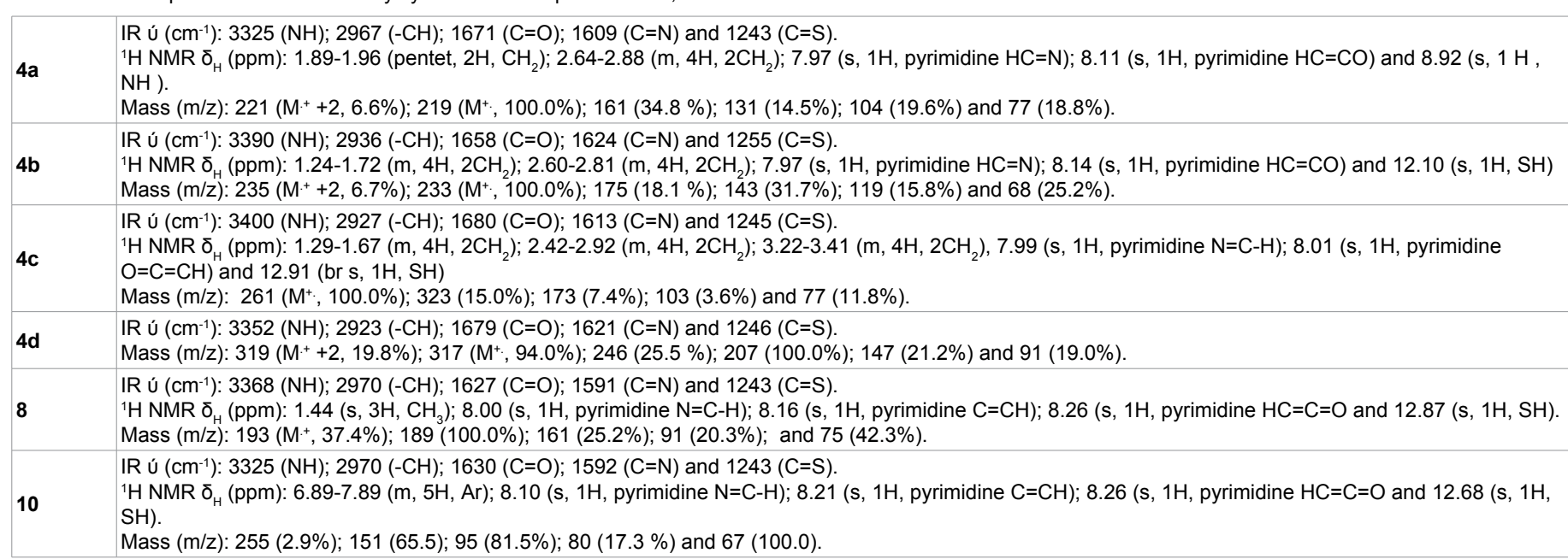

(Zoology Department, Faculty of Science, Beni-Suef University, Egypt) to exclude any intercurrent infection. They were supplied standard diet and tap water ad libitum, and maintained under suitable living conditions in good aerated cages at natural daily 12 hours dark-light cycle and at room temperature $20-25^{\circ} \mathrm{C}$. All animal procedures are in accordance with the recommendations of the Canadian Committee for Care and Use of Animals (CCAC) [26].

\section{Acute toxicity study and determination of $\mathrm{LD}_{50}$}

$\mathrm{LD}_{50}$ of the studied compound $\mathbf{4 b}$ was determined as described by Afifi et al. [27]. In this experiment, six groups each of 8 male albino mice weighing 20-25 g were used. One group serves as control and other groups of mice were orally administered the tested compound by gastric tube in gradual increasing doses $(200,400,600,800$ and 1000 $\mathrm{mg} / \mathrm{kg}$ b. w.). After 48 hours of administration, the number of dead animals in each group, the mean of dead animals in two successive doses $(\mathrm{z})$ and the constant factor between two successive doses $(\mathrm{d})$ were recorded and $\mathrm{LD}_{50}$ was calculated as follow:

\section{$\mathrm{LD}_{50}=$ the biggest dose which kill all animals $-\Sigma(\mathrm{z} . \mathrm{d}) / \mathrm{n}$}

Where n: number of animals in groups = eight animals in each group.

$\mathrm{LD}_{50}$ of albino rats was calculated from that of mice by using the conversion table of Paget and Barnes [28] and the therapeutic dose used for the subsequent studies was chosen based on the obtained $\mathrm{LD}_{50}$.

\section{Induction of type $\mathbf{2}$ diabetic rat model and treatment}

Type 2 diabetic (NIDDM) rats was induced by intraperitoneal injection of streptozotocin (Sigma Chemical Company, USA), at dose level of $120 \mathrm{mg} / \mathrm{kg} \mathrm{b}$. w. (dissolved in citrate buffer, $\mathrm{pH} \mathrm{4.5)} \mathrm{to} \mathrm{8-hour}$ fasted five-day-old albino rat pups according to Takada et al. [29]. The control counterpart rat pups were injected the equivalent volume of citrate solution by the same route. After 14 weeks post-STZ injection, the streptozotocin-injected rats were deprived of food and screened for hyperglycemia. Animals with serum glucose level after 2 hours of oral glucose loading ( $3 \mathrm{~g} / \mathrm{kg} \mathrm{b}$. w.) ranging from $180-300 \mathrm{mg} / \mathrm{dl}$ were considered mild diabetic and included in the experiment. Both mild diabetic male and female rats were separately divided into two groups each of 8 animals. One diabetic group was treated with pyrimido[1,6- $a]$ quinazoline derivative $\mathbf{4 b}$ at dose level of $10 \mathrm{mg}$ (dissolved in dimethyl sulfoxide, DMSO)/kg b. w./day by oral gavage for 3 weeks. The other diabetic group was daily administered the equivalent volume of the vehicle (DMSO) for the same period by the same route. The normal control was administered DMSO similarly to the diabetic control. At the day before sacrifice, animals of each group were deprived of food and oral glucose tolerance was performed by taking blood samples from lateral tail vein after $0,1,2$ and 3 hours of oral glucose load (3 g/ $\mathrm{kg} \mathrm{b}$. w.). At the next day, animals were sacrificed. Blood was obtained from cervical vein, left to coagulate and then centrifuged at 3000 r.p.m. for 15 minutes to obtain serum. Animals were rapidly dissected, and liver and pancreas were excised from each animal. Part of liver $(0.5$ g) from each rat was homogenized in $0.9 \%$ saline at $10 \% \mathrm{w} / \mathrm{v}$ and homogenate supernatant was separated by centrifugation at 3000 r.p.m. for 15 minutes. Serum and homogenate supernatant were kept in deep freezer at $-30^{\circ} \mathrm{C}$ till use for the determination of biochemical and oxidative stress markers. Another part of liver (1g) was used for 
glycogen determination. Pancreas was kept in $10 \%$ neutral buffered formalin for histological examination.

\section{Biochemical determinations}

Serum glucose was measured according to the method of Trinder [30] using reagent kit obtained from Chronolab AG (Switzerland). Serum insulin and C-peptide levels were measured in Radioactive Isotopes Unit, Middle Eastern Regional Radioisotope Center (Dokki, Giza) by radioimmunoassay kits of DPC (Diagnostic Products Corporation, Los Angeles, USA) according to the methods of Marschner et al. [31] and Beyer et al. [32] respectively. Hepatic glycogen content and glycogen phoshorylase, glucose-6-phosphatase and hexokinase activities were estimated according to the methods of Seifter et al. [33], Stalmans and Hers [34], Begum et al. [35] and Brastrup et al. [36] respectively. Hepatic hydroxymethylglutaryl Co-A reductase activity was determined based on the method of Venugopala Rao and Ramakrishan [37]. Serum total lipid concentration was detected according to the method of Frings et al. [38] using reagent kits purchased from Diamond Diagnostics (Egypt). Serum triglycerides, total cholesterol and HDL-cholesterol levels were determined according to the methods of Fossati and Prencipe [39] , Allain et al. [40] and Burnstein et al. [41] respectively, using reagent kits obtained from Reactivos Spinreact (Spain). Serum LDLcholesterol level was calculated from Friedewald [42] formula (LDLcholesterol $=$ total cholesterol - triglycerides $/ 5-$ HDL-cholesterol). Serum vLDL-cholesterol concentration was calculated according to Nobert [43] formula (vLDL-cholesterol = triglycerides/5). The ratios of total cholesterol and LDL-cholesterol to HDL-cholesterol were also calculated.

Hepatic levels of total thiol, glutathione and lipid peroxidation peroducts were estimated according to the methods of Koster et al. [44], Beutler et al. [45] and Preuss et al. [46] respectively. Hepatic glutathione reductase, glutathione peroxidase, glutathione-S-transferase and catalase activities were assayed according to the methods of Goldberg and Spooner, [47] Pinto and Bartley [48], Mannervik and Guthenberg [49] and Cohen et al. [50] respectively.

\section{Histological investigation}

The fixed specimens were routinely processed for embedding in paraffin wax and sectioning. Prepared sections were stained with modified aldehyde fuchsin stain method [51].

\section{Statistical analysis}

Data were analyzed by one way-ANOVA followed by LSD test to compare various groups with each other using statistical program PCSTAT (University of Georgia, USA) [52]. F-probability expresses the general effect between groups.

\section{Results and Discussion}

\section{Chemistry (synthesis)}

In this research work, our synthetic strategy commences from the easily available compound, 6-aminothiouracil and the sodium salts of formyl ketones, which led to the direct construction of the novel fused pyrimido[1,6-a]pyrimidine nucleus. Thus, fusion of 6-aminothiouracil with the formyl salts (1) in piperidine acetate and acetic acid afforded in considerable yields the cyclocondensed pyrimido $[1,6-a]$ pyrimidines 4a-d as outlined in chart (1) $[53,54,55]$.

The reaction mode for the formation of the products is suggested to proceed through the initial nucleophilic attack by the exocyclic amino group of 6-aminothiouracil at the formyl group of compound (2), that

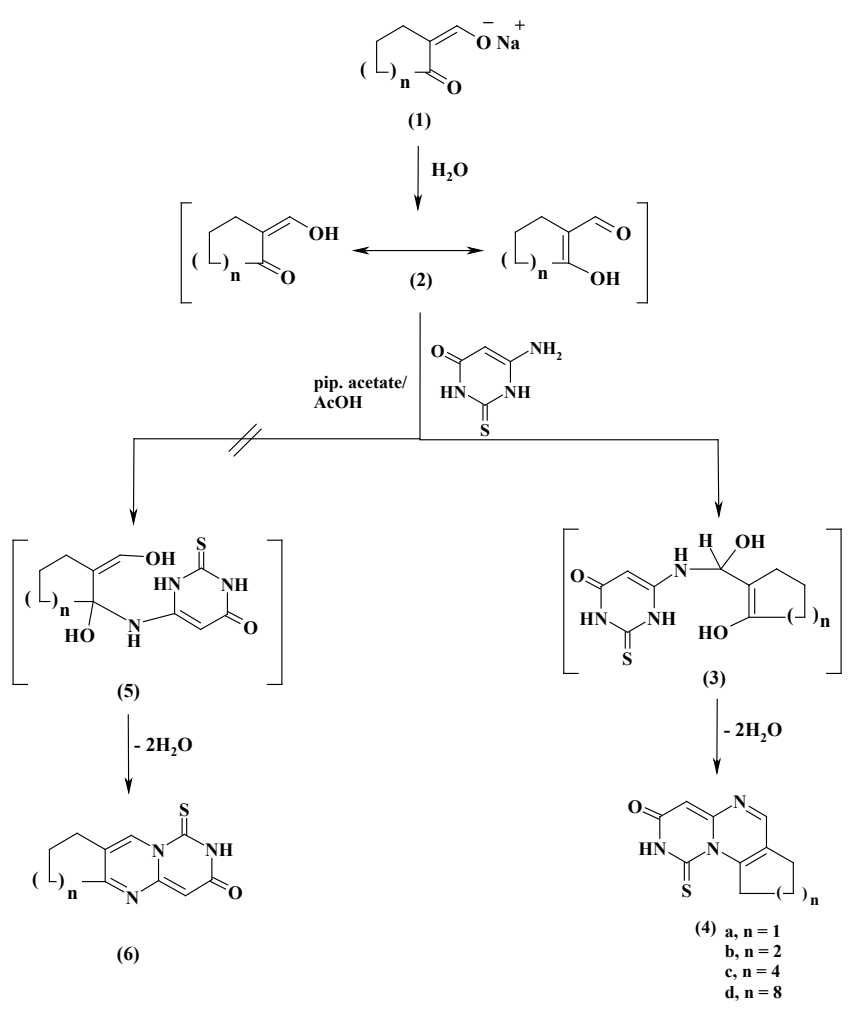

Chart 1:

formed in situ due to the reaction of the formyl salts (1) with water, followed by cyclization through the elimination of two water molecules leading to the formation of the non-planer products (4) rather than the planner products (6) [56-58].

The identity of compounds (3) was proven on the basis of their elemental analysis and spectral data. However, the nucleus of pyrimido $[1,6-a]$ pyrimidine has more than one resonating forms must be taken in consideration while we discuss their spectral data. This ring system may be found in the following three resonating forms:
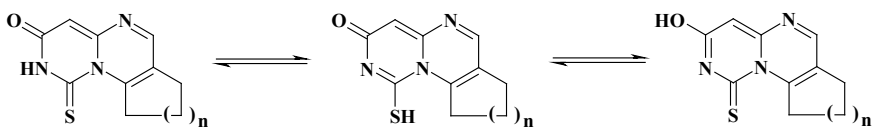

Thus, the IR of $4 \mathbf{c}$ revealed bands at $\dot{v}=3400 \mathrm{Cm}^{-1}(\mathrm{NH}) ; 2927$ (paraffinic $\mathrm{CH}) ; 1680(\mathrm{C}=\mathrm{O}) ; 1613(\mathrm{C}=\mathrm{N})$ and $1245(\mathrm{C}=\mathrm{S})$. The ${ }^{1} \mathrm{H}$ NMR spectrum showed signals at $\delta=1.29-1.67 \mathrm{ppm}\left(\mathrm{m}, 4 \mathrm{H}, 2 \mathrm{CH}_{2}\right)$; 2.42-2.92 (m, 4H, 2CH $) ; 3.22-3.41\left(\mathrm{~m}, 4 \mathrm{H}, 2 \mathrm{CH}_{2}\right), 7.99(\mathrm{~s}, 1 \mathrm{H}$ pyrimidine $\mathrm{N}=\mathrm{C}-\mathrm{H}) ; 8.01(\mathrm{~s}, 1 \mathrm{H}$, pyrimidine $\mathrm{C}=\mathrm{CH}$ ) and 12.91 (br s, $1 \mathrm{H}, \mathrm{SH})$. The mass spectrum of this compound showed a molecular ion peak at $\mathrm{m} / \mathrm{z}=261(100 \%)$, coincident with the molecular weight of the compound (261.35).

A successful trying for establishment of the cyclocondensation reaction has been carried out by the reaction of 6 -aminothiouracil with the sodium salts of acyclic ketones $\mathbf{7}$ and $\mathbf{9}$ under the same reaction conditions and following the same reaction mechanism to afford 4-methyl-6-thioxo-6,7-dihydro-8 $H$-pyrimido[1,6-a]pyrimidin8-one (8) and 4-phenyl-6-thioxo-6,7-dihydro- $8 \mathrm{H}$-pyrimido[1,6-a] pyrimidin-8-one (10) respectively Chart (2). 


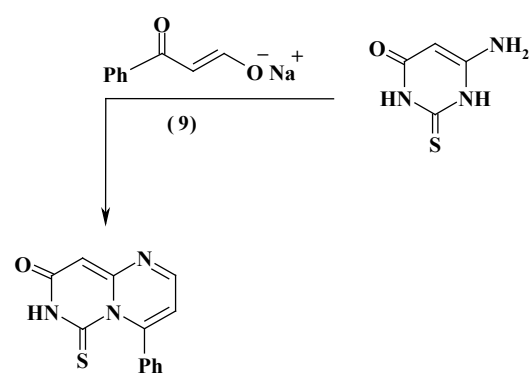

(10)

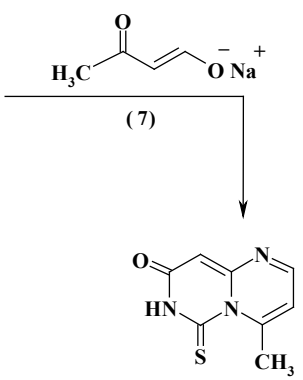

(8)
Chart 2:

The structure compound $\mathbf{8}$ was established by its correct elemental analysis and the IR spectrum which revealed bands at $\dot{v}=3368 \mathrm{Cm}^{-1}$ $(\mathrm{NH}) ; 1627(\mathrm{C}=\mathrm{O})$ and $1243(\mathrm{C}=\mathrm{S})$. The mass spectrum showed a molecular ion peak at $\mathrm{m} / \mathrm{z}=193(37.4 \%)$ coincident with its molecular weight (193.23) and the base peak appeared at $\mathrm{m} / \mathrm{z}=189(100 \%)$. The IR of compound 10 showed bands at $v=3325 \mathrm{Cm}^{-1}(\mathrm{NH}) ; 1630(\mathrm{C}=\mathrm{O})$ and $1243(\mathrm{C}=\mathrm{S})$. The mass spectrum showed the molecular ion peak at $\mathrm{m} / \mathrm{z}=255$ (1.7\%) coincident with its molecular weight (255.30).

\section{Biological studies}

For determination of lethal dose (LD) 50 of 1-thioxo-1,2,7,8,9,10hexahydro-3H-pyrimido[1,6-a] quinazolin-3-one $(\mathbf{4 b})$, single gradual increasing doses were administered to various groups of normal albino mice. The number of dead animals in each group was determined after 48 hours of compound administration and $\mathrm{LD}_{50}$ was calculated. $\mathrm{LD}_{50}$ of 4b was found to be $775 \mathrm{mg} / \mathrm{kg}$ b.w. for albino mice (Table 3). By using conversion table of Paget and Barnes [26], $\mathrm{LD}_{50}$ for rats was found to be $542 \mathrm{mg} / \mathrm{kg}$ b.w. Based on this toxicity study, the orally therapeutic dose for subsequent in vivo study was chosen to be $10 \mathrm{mg} / \mathrm{kg} \mathrm{b}$. w. (about $1 / 50$ of $\mathrm{LD}_{50}$ ) which is so far from $\mathrm{LD}_{50}$.

To assess the antihyperglycemic, antihyperlipidemic and antioxidant effects of pyrimido[1,6-a]quinazoline derivative (4b), neonatal streptozotocin (n-STZ)-induced type 2 diabetic rats were used. This $\mathrm{n}$-STZ rat model was chosen because it was previously reported that it has several advantages over other models and is considered to be one of the suitable experimental models of type 2 diabetes mellitus $[16,59]$.

The male and female adult n5-STZ rat model of the present study after 17 weeks of neonatal day 5 of STZ injection showed profound elevated basal serum glucose concentration, impaired glucose tolerance, decreased basal serum insulin, decreased number of islets and $\beta$-cells, lack of insulin response to glucose (due to $\beta$-cell glucose insensitivity), decreased liver glycogen content and hyperlipidemidia associated with increased serum levels of triglycerides, total cholesterol, LDLcholesterol, vLDL-cholesterol and higher ratios of LDL-cholesterol and total cholesterol to HDL-cholesterol in addition to the increase in the oxidative stress (Figures 1-4 and Tables 4-11). These results are in accordance with various several publications [60-66].

The treatment of male and female n5-STZ diabetic rats with pyrimido[1,6-a] quinazoline derivative $\mathbf{4 b}$ for three weeks beginning from the $14^{\text {th }}$ week to the $17^{\text {th }}$ week post-STZ injection at dose level of $10 \mathrm{mg} / \mathrm{kg}$ b. w. $\left(1 / 50 \mathrm{LD}_{50}\right)$ produced significant improvement $(\mathrm{p}<0.01$, LSD) of the impaired oral glucose tolerance (Figures 1 and 2). While the effect of treatment with $\mathbf{4 b}$ on glucose concentration at fasting state seemed to be more potent in male than female, the reverse was true at
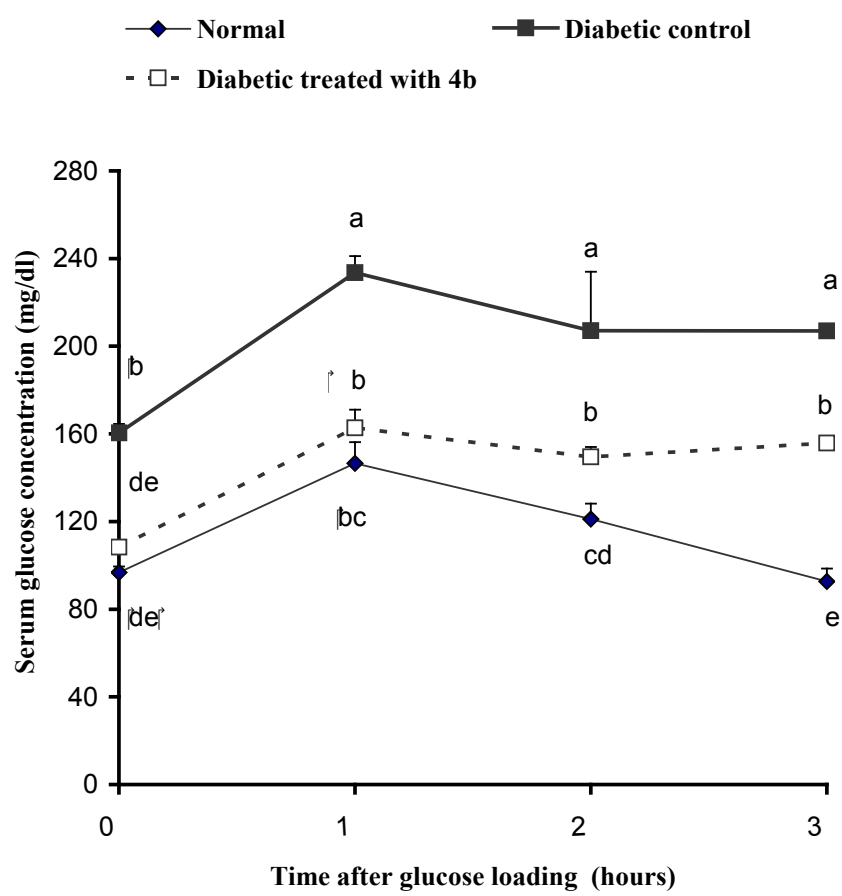

Figure 1: Effect of pyrimido[1,6-a]quinazoline derivative $4 \mathrm{~b}$ on oral glucose tolerance of n5-STZ-induced diabetic male rats.

F-probability: $\mathbf{p}<\mathbf{0 . 0 0 1}$; LSD at the $5 \%$ level: 27.42 ; LSD at the $1 \%$ level: 36.93

Values, which share the same superscript symbol(s), are not significantly different.
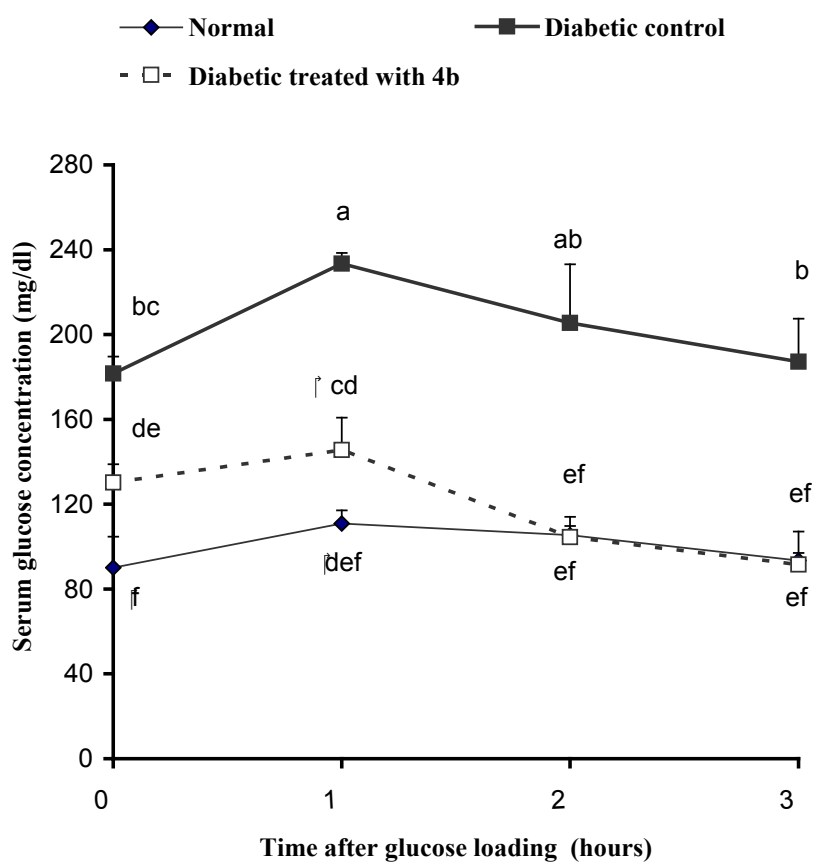

Figure 2: Effect of pyrimido[1,6- $a$ ]quinazoline derivative $4 \mathrm{~b}$ on oral glucose tolerance of n5-STZ-induced diabetic female rats.

F-probability: $\mathbf{p}<0.001$; LSD at the $5 \%$ level: 38.97 ; LSD at the $1 \%$ level: 52.49 .

Values, which share the same superscript symbol(s), are not significantly different. 
Citation: Ahmed OM, Hussein AM, Ahmed RR (2012) Antidiabetic and Antioxidant Effects of Newly Synthesized Pyrimido[1,6-A]Pyrimidine Derivatives in Neonatal Streptozotocin-Induced Diabetic Rats. Med chem 2: 020-028. doi:10.4172/2161-0444.1000108

2 and 3 hours post-oral glucose loading. This amelioration of glucose tolerance was associated with potential amelioration of the depleted basal and postprandial serum levels of insulin and C-peptide which is a marker of $\beta$-cells function and insulin secretion; the effect seemed to be more potent in male than female as a result of treatment. The increase of serum insulin and C-peptide levels as a result of treatment could be attributed to the remarkable amendment of the perturbed histological architecture of islets of Langerhans and increase in the diminished number of $\beta$-cells of diabetic rats (Figures 3 and 4) in addition to the improvement of the impaired insulin response to glucose (Tables 4 and 5), which is one of the main characteristics in $\mathrm{n}$-STZ diabetic rats [67]. The present study indicated that the insulin and C-peptide concentrations of n5-STZ diabetic control rats was not significantly affected after 2 hours of oral glucose loading as compared with the corresponding basal concentrations, while in n5STZ diabetic rats treated with $\mathbf{4 b}$, they were potentially increased. This reflects that the compound $\mathbf{4 b}$ may enhance the deteriorated insulin secretion in response to glucose in $\mathrm{n}-\mathrm{STZ}$ diabetic rats. Our results are in concurrence with those of other publications [22,28] which revealed that the treatment with $3 \mathrm{H}$-quinazolinone derivatives induced potential hypoglycemic and secretogouge effects in diabetic rats.

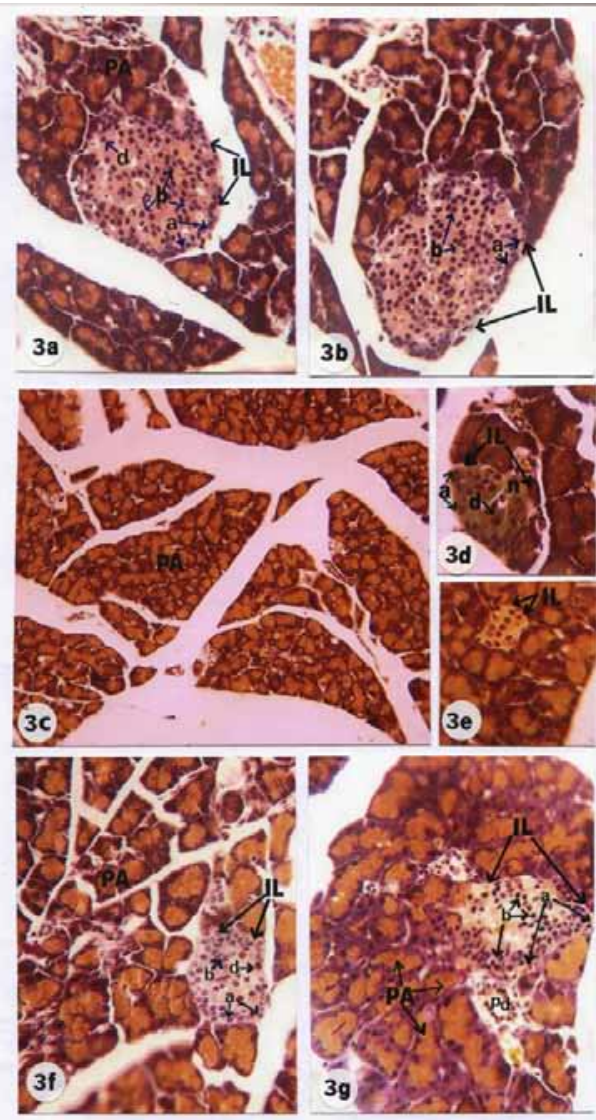

Figures 3: Photomicrographs of sections of pancreas of normal (Figures $3 a$ and $3 b$ ), diabetic control (Figures $3 c, 3 d$ and $3 e$ ) and diabetic treated (Figures $3 \mathrm{f}$ and $3 \mathrm{~g}$ ) male rats. Normal rats showed intact islets of Langerhans (IL) with alpha cells (a) at the periphery, beta cells (b) in the core and delta cells (d) adjacent to beta cells with enlarged size. Diabetic rats showed absence of islets at almost all area of pancreas parenchyma (PA) (Figure $3 c$ ) or presence of little number of small-sized islets (Figures $3 d$ and $3 e$ ) with necrosis $(n)$. Diabetic rats treated with $4 b$ exhibited marked increase in the number and size of islets with relatively increased number of islet cells $(a, b$ and d). Pancreatic ductule (bd) is also visible.

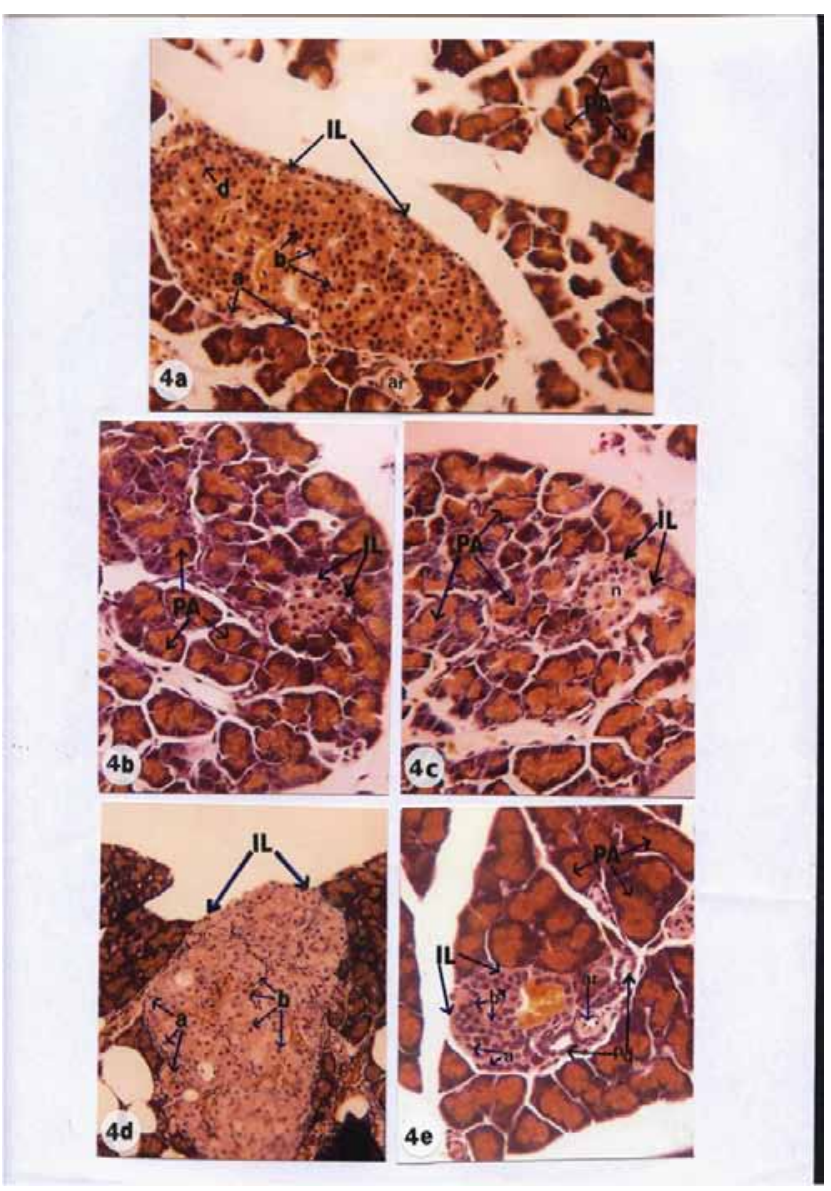

Figures 4: Photomicrographs of sections of pancreas of normal (Figures 4a), diabetic control (Figures $4 \mathrm{~b}$ and $3 \mathrm{c}$ ) and diabetic treated (Figures $4 \mathrm{~d}$ and $4 \mathrm{e}$ ) female rats. Normal rats showed intact islets of Langerhans (IL) with alpha cells (a) at the periphery, beta cells (b) in the core and delta cells (d) adjacent to beta cells with enlarged size. Diabetic rats showed a deleterious decrease in the size of islets (Figures $4 \mathrm{~d}$ and $4 \mathrm{e}$ ) with necrosis (n). Diabetic rats treated with $4 \mathrm{~b}$ exhibited marked increase in the size of islets and number of islet cells (a and b). Pancreatic ductule (bd) and pancreatic artery (ar) are also visible.

To elucidate the probable mechanism of hypoglycemic action of $\mathbf{4 b}$ in diabetic rats, the activities of some hepatic enzymes (Tables 6 and 7), which may be concerned with glucose metabolism as well as uptake and production of glucose by the liver, were detected. The study revealed that the elevated liver glycogen phosphorylase and glucose6-phosphatase activities in diabetic rats were detectably decreased in $\mathrm{n} 5$-STZ as a result of $\mathbf{4 b}$ treatment. In contrast, the hepatic hexokinase activity was significantly increased in n5-STZ diabetic rats treated with $\mathbf{4 b}$ as compared with the diabetic control counterparts. Concomitant with these changes, liver glycogen content which may also be considered as one of the best markers of antihyperglycemic effect of any drug [68] was detectably ameliorated after treatment of n5-STZ diabetic rats with $\mathbf{4 b}$ (Tables 6 and 7). These previous changes led us to suggest that the tested pyrimido[1,6-a]quinazoline derivative (4b) may produce hypoglycemic effects in n5-STZ type 2 diabetic rats via decreasing hepatic glucose production and increasing glucose uptake which possibly due to enhancing blood insulin level and tissue insulin action. In concurrence with the present study, Mukherjee et al. [69] found that centpiperalone, $3 \mathrm{H}$-quinazolinone derivative, enhanced glucose uptake into rat hemidiagrams. 
Table 3: Determination of $L_{50}$ of pyrimido[1,5-a]quinazoline derivative (4b) in albino mice.

\begin{tabular}{|c|c|c|c|c|c|}
\hline Dose (mg/kg b. w.) & Total number of animals & Number of dead animals & $z$ & d & $\sum($ z.d) \\
\hline 200 & 8 & 0 & - & - & - \\
\hline 400 & 8 & 1 & 0.5 & 200 & 100 \\
\hline 600 & 8 & 2 & 1.5 & 200 & 300 \\
\hline 800 & 8 & 4 & 3 & 200 & 600 \\
\hline 1000 & 8 & 6 & 5 & 200 & 1000 \\
\hline 1200 & 8 & 8 & 7 & 200 & 1400 \\
\hline
\end{tabular}

z: mean number of dead animals in two successive doses

$\mathrm{d}$ : constant factor between two successive doses

$\mathrm{LD}_{50}=$ the biggest dose which kill all animals $-\sum(\mathrm{z} . \mathrm{d}) / \mathrm{n}=1200-3400 / 8=775 \mathrm{mg} / \mathrm{kg} \mathrm{b}$. $\mathrm{w}$.

By using the conversion table of Paget and Barnes (1964), LD50 for rats was calculated from that of mice and was found to be $542.5 \mathrm{mg} / \mathrm{kg} \mathrm{b}$. $\mathrm{w}$.

$1 / 50$ of $L D_{50}$ is about $10 \mathrm{mg} / \mathrm{kg} \mathrm{b}$. w. which was considered as sublethal dose that used as therapeutic dose in the subsequent work

Table 4: Effect of pyrimido[1,6-a]quinazoline derivative $4 \mathrm{~b}$ on serum insulin and C-peptide levels at fasting state and after 2 hours of oral glucose loading in n5-STZ induced type 2 diabetic male rats.

\begin{tabular}{|c|c|c|c|c|}
\hline \multirow[b]{2}{*}{ Groups } & \multicolumn{2}{|c|}{ Insulin $(\mu \mathrm{lU} / \mathrm{mL})$} & \multicolumn{2}{|c|}{ C-peptide (pmol/mL) } \\
\hline & Fasting & 2 hours & Fasting & 2 hours \\
\hline Normal control & $25.23 \pm 1.83^{b}$ & $36.43 \pm 2.26^{a}$ & $160.67 \pm 6.41^{\mathrm{bc}}$ & $147.65 \pm 5.74^{\mathrm{a}}$ \\
\hline Diabetic control & $10.01 \pm 0.76^{c}$ & $10.80 \pm 0.54^{c}$ & $58.05 \pm 13.85^{d}$ & $64.05 \pm 12.33^{d}$ \\
\hline Diabetic treated with $4 b$ & $31.36 \pm 3.30^{\mathrm{ab}}$ & $36.88 \pm 6.64^{a}$ & $141.97 \pm 2.04^{c}$ & $194.14 \pm 23.23^{b}$ \\
\hline F-probability & \multicolumn{2}{|l|}{$\mathrm{P}<0.001$} & \multicolumn{2}{|l|}{$P<0.001$} \\
\hline LSD at the $5 \%$ level & \multicolumn{2}{|l|}{9.46} & \multicolumn{2}{|l|}{36.56} \\
\hline LSD at the $1 \%$ level & \multicolumn{2}{|l|}{12.74} & \multicolumn{2}{|l|}{49.24} \\
\hline
\end{tabular}

- Data are expressed as mean \pm standard error. Number of animals in each group is eight.

- For each parameter, means, which share the same superscript symbol(s), are not significantly different.

- If the difference between two means is higher than LSD at $5 \%$, the effect will be significant $(p<0.05)$.

- If the difference between two means is higher than LSD at $1 \%$, the effect will be highly significant $(p<0.01)$.

Table 5: Effect of pyrimido[1,6- $a$ ]quinazoline derivative $4 \mathrm{~b}$ on serum insulin and C-peptide levels at fasting state and after 2 hours of oral glucose loading in n5-STZ induced type 2 diabetic female rats.

\begin{tabular}{|c|c|c|c|c|}
\hline \multirow[b]{2}{*}{ Groups } & Parameters & Insulin $(\mu \mathrm{lU} / \mathrm{mL})$ & \multicolumn{2}{|c|}{ C-peptide (pmol/mL) } \\
\hline & Fasting & 2 hours & Fasting & 2 hours \\
\hline Normal control & $30.73 \pm 4.83^{b}$ & $41.91 \pm 0.64^{a}$ & $158.60 \pm 6.26^{b}$ & $209.23 \pm 21.88^{a}$ \\
\hline Diabetic control & $13.66 \pm 1.54^{c}$ & $14.40 \pm 1.79^{c}$ & $47.85 \pm 3.46^{d}$ & $58.74 \pm 3.95^{\mathrm{cd}}$ \\
\hline Diabetic treated with $4 \mathrm{~b}$ & $29.90 \pm 5.25^{b}$ & $34.41 \pm 5.60^{\mathrm{ab}}$ & $65.19 \pm 3.40^{\text {cd }}$ & $172.17 \pm 10.03^{b}$ \\
\hline F-probability & \multicolumn{2}{|l|}{$P<0.001$} & \multicolumn{2}{|l|}{$P<0.001$} \\
\hline LSD at the $5 \%$ level & \multicolumn{2}{|l|}{11.07} & \multicolumn{2}{|l|}{29.91} \\
\hline LSD at the $1 \%$ level & \multicolumn{2}{|l|}{14.91} & \multicolumn{2}{|l|}{40.29} \\
\hline
\end{tabular}

Table 6: Effect of pyrimido[1,6-a]quinazoline derivative 4b on liver glycogen content and glycogen phosphorylase, glucose-6-phosphatase and hexokinase activities in n5-STZ induced type 2 diabetic male rats.

\begin{tabular}{|c|c|c|c|c|c|}
\hline Groups & Parameters & Glycogen (mg/g tissue) & $\begin{array}{l}\text { Glycogen phosphorylase } \\
\text { (mU/100mg tissue) }\end{array}$ & $\begin{array}{l}\text { Glucose-6-phosphatase } \\
\text { (mU/100mg tissue) }\end{array}$ & Glucokinase (mU/100mg tissue) \\
\hline Normal control & & $6.96 \pm 0.98^{a}$ & $11.39 \pm 0.32^{b}$ & $21.97 \pm 0.56^{b}$ & $32.52 \pm 0.17^{b}$ \\
\hline Diabetic control & & $4.56 \pm 0.29^{b}$ & $21.46 \pm 3.64^{a}$ & $31.32 \pm 2.37^{\mathrm{a}}$ & $32.82 \pm 0.83^{b}$ \\
\hline Diabetic treated with $4 b$ & & $5.56 \pm 0.28^{\mathrm{ab}}$ & $11.10 \pm 0.91^{\mathrm{b}}$ & $29.05 \pm 1.07^{a}$ & $44.65 \pm 2.07^{\mathrm{a}}$ \\
\hline F-probability & & $P<0.05$ & $P<0.01$ & $P<0.01$ & $\mathrm{P}<0.001$ \\
\hline LSD at the $5 \%$ level & & 1.84 & 6.56 & 4.61 & 4.84 \\
\hline LSD at the $1 \%$ level & & 2.55 & 9.07 & 6.38 & 6.69 \\
\hline
\end{tabular}

It is also interesting, in the present study, to find that pyrimido [1,6- $a]$ quinazoline derivative $\mathbf{4 b}$ produced antihyperlipidemic efficacy which was indicated by potential decreases in the levels of serum total lipids, triglycerides, total cholesterol, LDL-cholesterol and vLDL-cholesterol in both male and female diabetic rats. Hepatic hydroxymethylglutaryl-CoA (HMG-CoA) reductase, the key enzyme responsible for cholesterol synthesis [70], indicated by the ratio of HMG-CoA to mevalonate, was non-significantly affected $(\mathrm{p}>0.05)$ or significantly increased $(\mathrm{p}<0.01)$ respectively in female and male n5-STZ diabetic rats treated with the tested compound as compared with the diabetic counterparts (Tables 6 and 7). Based on these results, it can be concluded that the decrease in serum cholesterol levels after treatment of n5-STZ was not attributed to the effects of $4 \mathbf{b}$ on cholesterol synthesis, but may be due to the enhancement of the clearance rate of cholesterol from the blood through upregulation of LDL-receptor and tissue lipoprotein lipase (LPL) activity [71,72] and/ or decreases in intestinal cholesterol absorption. In support to the latter postulation, Refaie et al. [23] suggested that antihypercholesterolemic effects of quinazolinone compound was brought about by inhibition of dietary cholesterol absorption.

Cadiovascular risk indices, represented by the ratios of LDLcholesterol and total cholesterol to HDL-cholesterol, were significantly increased $(\mathrm{p}<0.01)$ in the $\mathrm{n} 5$-STZ diabetic male and female rats. The treatment with $4 \mathrm{~b}$ solely induced significant $(\mathrm{p}<0.01)$ improvement of 
the elevated total cholesterol: HDL-cholesterol ratio in diabetic male rats (Tables 8 and 9).

To evaluate the effect of pyrimido[1,6-a]quinazoline derivative $\mathbf{4 b}$ on oxidative stress and antioxidant defense system in type 2 diabetic male and female rat model, liver levels of total thiol, glutathione, glutathione reductase, glutathione peroxidase, glutathione-Stransferase, lipid peroxidation products and catalase were investigated and presented in tables 10 and 11 . The treatment of diabetic male and female rats with $4 \mathrm{~b}$ induced a profound increase in hepatic total thiol and glutathione concentration as well as glutathione peroxidase activity. Moreover, the elevated lipid peroxidation in diabetic male and female rats was significantly alleviated as a result of $4 \mathrm{~b}$ treatment. This result was in consonance with that obtained by de la Cruz et al. [10] who revealed that 3 pyrimido-pyrimidine derivatives inhibited lipid peroxidation in human liver membranes. It is noteworthy to recognize that in diabetes, protein glycation and glucose auto-oxidation can lead to the formation of free radicals and induction of lipid peroxidation in several organs [73]. Thus, the improvement in the elevated levels of blood glucose and glycated proteins secondary to amelioration of insulin level and action may in turn lead to decrease of the formation of free radicals and attenuation of lipid peroxidation [64]. However, the glutathione reductase, glutathione-S-transferase and catalase activities were not significantly altered after treatment of diabetic rats with $4 \mathrm{~b}$. Overall, based on these results, it can be suggested that the tested pyrimido[1,6-a]quinazoline derivative $4 \mathbf{b}$ may have antioxidant activities in 5 -STZ diabetic male and female rats.

\section{Conclusions}

In this investigation, it has been found that the novel synthetic 1-thioxo-1,2,7,8,9,10-hexahydro-3H-pyrimido[1,6-a]quinazolin-3one has antihyperglycemic and antihyperlipidemic potentials in n5STZ induced type 2 diabetic male and female rats. These effects may be

Table 7: Effect of pyrimido[1,6-a]quinazoline derivative 4b on liver glycogen content and glycogen phosphorylase, glucose-6-phosphatase and hexokinase activities in n5-STZ induced type 2 diabetic female rats.

\begin{tabular}{|l|l|l|l|l|}
\hline \multicolumn{1}{|c|}{ Parameters } & Glycogen (mg/g tissue) & $\begin{array}{l}\text { Glycogen phosphorylase } \\
(\mathrm{mU} / 100 \mathrm{mg} \text { tissue) }\end{array}$ & Glucose-6-phosphatase (mU/100mg tissue) & Glucokinase (mU/100mg tissue) \\
\hline Normal control & $8.20 \pm 0.32^{\mathrm{a}}$ & $14.15 \pm 1.14^{\mathrm{b}}$ & $28.04 \pm 1.01^{\mathrm{b}}$ & $50.93 \pm 6.09^{\mathrm{a}}$ \\
\hline Diabetic control & $4.63 \pm 0.39^{\mathrm{c}}$ & $29.36 \pm 3.29^{\mathrm{a}}$ & $32.89 \pm 1.53^{\mathrm{a}}$ & $56.89 \pm 8.49^{\mathrm{a}}$ \\
\hline Diabetic treated with 4b & $6.74 \pm 0.41^{\mathrm{b}}$ & $12.79 \pm 1.04^{\mathrm{b}}$ & $28.97 \pm 1.21^{\mathrm{b}}$ & $\mathrm{P}<0.05$ \\
\hline F-probability & $\mathrm{P}<0.001$ & $\mathrm{P}<0.001$ & 3.82 & $-65 \pm 8.96^{\mathrm{a}}$ \\
\hline LSD at the 5\% level & 1.14 & 6.32 & 5.29 & - \\
\hline LSD at the 1\% level & 1.58 & 8.74 & - \\
\hline
\end{tabular}

Table 8: Effect of pyrimido[1,6- $a$ ]quinazoline derivative 4b on serum lipid profile in n5-STZ induced type 2 diabetic male rats.

\begin{tabular}{|c|c|c|c|c|c|c|c|c|c|}
\hline Groups & $\begin{array}{l}\text { Total lipids } \\
(\mathrm{g} / \mathrm{L})\end{array}$ & $\begin{array}{l}\text { Triglycerides } \\
\text { (mg/dl) }\end{array}$ & $\begin{array}{c}\text { Total } \\
\text { cholesterol } \\
\text { (mg/dl) }\end{array}$ & $\begin{array}{l}\text { LDL- } \\
\text { cholesterol } \\
\text { (mg/dl) }\end{array}$ & $\begin{array}{l}\text { HDL- } \\
\text { cholesterol } \\
(\mathrm{mg} / \mathrm{dl})\end{array}$ & $\begin{array}{l}\text { vLDL- } \\
\text { cholesterol } \\
\text { (mg/dl) }\end{array}$ & $\begin{array}{l}\text { LDL/ } \\
\text { HDL }\end{array}$ & $\begin{array}{l}\text { Total chol./ } \\
\text { HDL }\end{array}$ & $\begin{array}{l}\text { HMGCo-A/ } \\
\text { mevalonate }\end{array}$ \\
\hline Normal & $3.16 \pm 0.19^{c}$ & $42.75 \pm 1.37^{a}$ & $72.76 \pm 1.24^{b}$ & $29.90 \pm 0.63^{b}$ & $34.44 \pm 1.04^{\mathrm{a}}$ & $8.55 \pm 0.27^{a}$ & $0.87 \pm 0.02^{b}$ & $2.11 \pm 0.05^{b}$ & $1.31 \pm 0.01^{\mathrm{b}}$ \\
\hline Diabetic control & $4.71 \pm 0.20^{\mathrm{a}}$ & $46.07 \pm 2.38^{a}$ & $76.76 \pm 1.17^{a}$ & $37.49 \pm 2.79^{a}$ & $30.05 \pm 1.22^{\mathrm{a}}$ & $9.21 \pm 0.07^{a}$ & $1.27 \pm 0.12^{\mathrm{a}}$ & $2.56 \pm 0.06^{a}$ & $1.30 \pm 1.01^{\mathrm{b}}$ \\
\hline $\begin{array}{l}\text { Diabetic treated } \\
\text { with } 4 b\end{array}$ & $4.03 \pm 0.08^{b}$ & $42.28 \pm 0.54^{a}$ & $67.89 \pm 0.90^{c}$ & $25.77 \pm 1.55^{b}$ & $33.67 \pm 2.33^{a}$ & $8.46 \pm 0.30^{\mathrm{a}}$ & $1.31 \pm 0.06^{\mathrm{a}}$ & $2.06 \pm 0.12^{b}$ & $1.59 \pm 2.10^{\mathrm{a}}$ \\
\hline F-probability & $P<0.001$ & $p>0.05$ & $\mathrm{P}<0.001$ & $P<0.01$ & $p>0.05$ & $p>0.05$ & $P<0.01$ & $P<0.01$ & $P<0.001$ \\
\hline LSD at $5 \%$ level & 0.49 & - & 3.36 & 5.65 & - & - & 0.236 & 0.25 & 0.042 \\
\hline LSD at $1 \%$ level & 0.68 & - & 4.65 & 7.82 & - & - & 0.326 & 0.35 & 0.058 \\
\hline
\end{tabular}

Table 9: Effect of pyrimido[1,6- $a$ ]quinazoline derivative 4b on serum lipid profile in n5-STZ induced type 2 diabetic female rats.

\begin{tabular}{|c|c|c|c|c|c|c|c|c|c|}
\hline Groups & $\begin{array}{l}\text { Total lipids } \\
(\mathrm{g} / \mathrm{L})\end{array}$ & $\begin{array}{l}\text { Triglycerides } \\
\text { (mg/dl) }\end{array}$ & $\begin{array}{c}\text { Total } \\
\text { cholesterol } \\
(\mathrm{mg} / \mathrm{dl})\end{array}$ & $\begin{array}{l}\text { LDL- } \\
\text { cholesterol } \\
(\mathrm{mg} / \mathrm{dl})\end{array}$ & $\begin{array}{l}\text { HDL- } \\
\text { cholesterol } \\
\text { (mg/dl) }\end{array}$ & $\begin{array}{l}\text { vLDL- } \\
\text { cholesterol } \\
\text { (mg/dl) }\end{array}$ & $\begin{array}{l}\text { LDL/ } \\
\text { HDL }\end{array}$ & $\begin{array}{l}\text { Total chol./ } \\
\text { HDL }\end{array}$ & $\begin{array}{l}\text { HMGCo-A/ } \\
\text { mevalonate }\end{array}$ \\
\hline Normal & $3.46 \pm 0.18^{b}$ & $37.48 \pm 1.31^{\mathrm{b}}$ & $68.61 \pm 3.55^{b}$ & $27.84 \pm 0.28^{b}$ & $33.27 \pm 1.57^{a}$ & $7.49 \pm 0.26^{b}$ & $0.88 \pm 0.05^{b}$ & $2.07 \pm 0.09^{b}$ & $1.36 \pm 0.04^{b}$ \\
\hline Diabetic control & $4.82 \pm 0.34^{\mathrm{a}}$ & $46.35 \pm 2.14^{\mathrm{a}}$ & $80.12 \pm 1.77^{a}$ & $42.83 \pm 1.76^{a}$ & $28.14 \pm 1.24^{a}$ & $9.27 \pm 0.43^{a}$ & $1.54 \pm 0.11^{\mathrm{a}}$ & $2.87 \pm 0.18^{a}$ & $1.59 \pm 0.02^{\mathrm{a}}$ \\
\hline $\begin{array}{l}\text { Diabetic treated } \\
\text { with } 4 b\end{array}$ & $3.47 \pm 0.07^{b}$ & $36.50 \pm 081^{b}$ & $76.13 \pm 2.47^{\mathrm{ab}}$ & $42.62 \pm 1.83^{a}$ & $27.67 \pm 2.65^{a}$ & $7.30 \pm 0.16^{b}$ & $1.58 \pm 0.09^{a}$ & $2.85 \pm 0.21^{a}$ & $1.60 \pm 0.03^{a}$ \\
\hline F-probability & $P<0.01$ & $\mathrm{P}<0.001$ & $P<0.05$ & $P<0.001$ & $P>0.05$ & $\mathrm{P}<0.001$ & $P<0.001$ & $P<0.01$ & $\mathrm{P}<0.001$ \\
\hline LSD at $5 \%$ level & 0.68 & 4.59 & 8.13 & 4.45 & - & 0.92 & 0.256 & 0.511 & 0.103 \\
\hline LSD at $1 \%$ level & 0.94 & 6.35 & 11.24 & 6.16 & - & 1.27 & 0.355 & 0.706 & 0.144 \\
\hline
\end{tabular}

Table 10: Effect of pyrimido[1,6-a]quinazoline derivative 4b on oxidative stress and antioxidant defense markers in liver of n5-STZ induced type 2 diabetic male rats.

\begin{tabular}{|c|c|c|c|c|c|c|c|}
\hline Groups $\quad$ Parameters & $\begin{array}{l}\text { Total thiol } \\
\text { (nmole/100mg) }\end{array}$ & $\begin{array}{l}\text { Glutathione } \\
\text { (nmole/100mg) }\end{array}$ & $\begin{array}{l}\quad \text { Lipid } \\
\text { Peroxidation } \\
\text { (nmole MDA/100mg) }\end{array}$ & $\begin{array}{l}\text { Glutathione } \\
\text { reductase } \\
(\mathrm{U} / \mathrm{g})\end{array}$ & $\begin{array}{l}\text { Glutathione } \\
\text { peroxidase } \\
(\mathrm{mU} / 100 \mathrm{mg})\end{array}$ & $\begin{array}{l}\text { Glutathione-S- } \\
\text { transferase } \\
(\mathrm{U} / 100 \mathrm{mg})\end{array}$ & $\begin{array}{l}\text { Catalase } \\
\left(\mathrm{k} .10^{2}\right)\end{array}$ \\
\hline Normal & $247.13 \pm 0.94^{b}$ & $56.78 \pm 2.39^{\mathrm{ab}}$ & $51.65 \pm 1.27^{a}$ & $12.02 \pm 0.19^{a}$ & $96.20 \pm 4.61^{b}$ & $37.71 \pm 3.38^{a}$ & $71.85 \pm 1.63^{a}$ \\
\hline Diabetic control & $203.50 \pm 0.90^{c}$ & $53.50 \pm 0.90^{\mathrm{b}}$ & $54.65 \pm 0.02^{\mathrm{a}}$ & $11.20 \pm 0.31^{\mathrm{ab}}$ & $77.80 \pm 0.67^{c}$ & $40.68 \pm 2.43^{a}$ & $61.55 \pm 3.69^{a}$ \\
\hline $\begin{array}{l}\text { Diabetic treated } \\
\text { with } 4 b\end{array}$ & $257.32 \pm 1.91^{\mathrm{a}}$ & $60.49 \pm 0.89^{a}$ & $45.27 \pm 2.58^{b}$ & $10.89 \pm 0.32^{b}$ & $120.97 \pm 3.25^{a}$ & $21.28 \pm 1.63^{a}$ & $72.33 \pm 4.32^{a}$ \\
\hline F-probability & $P<0.001$ & $P<0.05$ & $P<0.01$ & $P<0.05$ & $P<0.001$ & $p>0.05$ & $p>0.05$ \\
\hline LSD at the $5 \%$ level & 4.03 & 4.71 & 5.01 & 0.85 & 9.87 & - & - \\
\hline LSD at the $1 \%$ level & 5.57 & 6.51 & 6.93 & 1.17 & 13.66 & - & - \\
\hline
\end{tabular}


Citation: Ahmed OM, Hussein AM, Ahmed RR (2012) Antidiabetic and Antioxidant Effects of Newly Synthesized Pyrimido[1,6-A]Pyrimidine Derivatives in Neonatal Streptozotocin-Induced Diabetic Rats. Med chem 2: 020-028. doi:10.4172/2161-0444.1000108

Table 11: Effect of pyrimido[1,6- $a$ ]quinazoline derivative $4 \mathrm{~b}$ on oxidative stress and antioxidant defense markers in liver of n5-STZ induced type 2 diabetic female rats.

\begin{tabular}{|c|c|c|c|c|c|c|c|}
\hline Parameters & $\begin{array}{l}\text { Total thiol } \\
\text { (nmole/100mg) }\end{array}$ & $\begin{array}{l}\text { Glutathione } \\
\text { (nmole/100mg) }\end{array}$ & $\begin{array}{l}\quad \text { Lipid } \\
\text { Peroxidation } \\
\text { (nmole MDA/100mg) }\end{array}$ & $\begin{array}{l}\text { Glutathione } \\
\text { reductase } \\
(\mathrm{U} / \mathrm{g})\end{array}$ & $\begin{array}{l}\text { Glutathione } \\
\text { peroxidase } \\
(\mathrm{mU} / 100 \mathrm{mg})\end{array}$ & $\begin{array}{l}\text { Glutathione-S- } \\
\text { transferase } \\
(\mathrm{U} / 100 \mathrm{mg})\end{array}$ & $\begin{array}{l}\text { Catalase } \\
\left(\mathrm{k} .10^{2}\right)\end{array}$ \\
\hline Normal & $241.72 \pm 4.59^{a}$ & $63.13 \pm 2.94^{a}$ & $44.27 \pm 1.38^{\mathrm{ab}}$ & $10.88 \pm 0.90^{\mathrm{a}}$ & $96.30 \pm 1.18^{b}$ & $33.52 \pm 23.78^{\mathrm{a}}$ & $60.27 \pm 0.99^{b}$ \\
\hline Diabetic control & $203.33 \pm 14.33^{b}$ & $54.93 \pm 1.56^{b}$ & $48.92 \pm 4.29^{a}$ & $10.24 \pm 0.03^{a}$ & $88.87 \pm 1.67^{b}$ & $26.62 \pm 2.05^{b}$ & $72.08 \pm 3.35^{a}$ \\
\hline $\begin{array}{l}\text { Diabetic treated } \\
\text { with } 4 b\end{array}$ & $235.85 \pm 4.13^{a b}$ & $59.85 \pm 0.83^{\mathrm{ab}}$ & $37.23 \pm 1.84^{b}$ & $10.58 \pm 0.28^{a}$ & $134.1 \pm 10.35^{a}$ & $26.45 \pm 1.64^{b}$ & $57.38 \pm 5.79^{b}$ \\
\hline F-probability & $P<0.05$ & $P<0.05$ & $P<0.05$ & $P>0.05$ & $P<0.001$ & $P<0.05$ & $P<0.05$ \\
\hline LSD at the $5 \%$ level & 27.16 & 5.95 & 8.48 & - & 8.17 & 6.17 & 11.76 \\
\hline LSD at the $1 \%$ level & 37.55 & 8.23 & 11.73 & - & 11.29 & 8.53 & 16.27 \\
\hline
\end{tabular}

due insulinogenic action and extrapancreatic effects in addition to the enhancing action on the antioxidant defense system. However, further clinical studies are required to assess the safety and efficacy of the tested compounds in diabetic human beings.

\section{Declaration of interest}

The authors report no conflicts of interest. The work was partially funded by the Faculty of Science, Beni-Suef University, Egypt.

\section{References}

1. Bedi J, Blasko G, Palos LA (1979) The effect of some pyrimido-pyrimidine derivatives on blood coagulation and platelet aggregation. Arzeimittelforschung 29: $1405-1408$.

2. Ram VJ, Goel A, Sarkhel S, Maulik PR (2002) A convenient synthesis and hepatoprotective activity of imidazo[1,2-c]pyrimido[5,4-e]pyrimidine, tetraazaacenaphthene and tetraazaphenalene from cyclic ketene aminals through tandem addition-cyclization reactions. Bioorg Med Chem 10: 12751280.

3. Delia TJ, Baumann M, Bunker A (1993) A procedure for the preparation of 4-(2-cyanoethyl) benzoic acid. Heterocycles 35: 1397-1410.

4. Solca FF, Baum A, Kopt EL, Dahmann G, Heider KH et al. (2004) Inhibition of epidermal growth factor receptor activity by two pyrimidopyrimidine derivatives. J Pharmacol Exp Therap 311: 502-509.

5. Coates WJ (1990) European Patent 351058. Chem Abstr 113: 40711.

6. Taylor EC, Knopf RJ, Meyer RF, Holmes A, Hoefle ML (1960) Pyrimido[4,5-d] pyrimidines. Part I J Am Chem Soc 82: 5711-5718.

7. Figueroa Villar JD, Carneiro CL, Cruz ER (1992) Synthesis of 6-phenylaminofuro[2,3-d]-pyrimidine-2, $4(1 \mathrm{H}, 3 \mathrm{H})$-diones from barbiturylidenes and isonitriles. Heterocycles 34: 891-893.

8. Kitamura N, Onishi A (1984) European Patent 163599. Chem Abstr 104 186439

9. Raddatz P, Bergmann R (1988) German Patent 360731. Chem Abstr 109: 54786.

10. De la Cruz JP, Carrasco T, Ortega G, Sanchez de la Cuesta F (1992) Inhibition of ferrous-induced lipid peroxidation by pyrimido-pyrimidine derivatives in human liver membranes. Lipids 27: 192-194.

11. Snider BB, Shi Z (1993) Biomimetic synthesis of (.+-.)-crambines A, B, C1, and $\mathrm{C} 2$. Revision of the structure of crambines B and C1. J Org Chem 58: 3828-3839.

12. Patil AD, Kumar NV, Kokke WC, Bean MF, Freyer AJ, et al (1995) Nove Alkaloids from the Sponge Batzella sp: Inhibitors of HIV gp120-Human CD4 Binding. J Org Chem 60: 1182-1188.

13. World Health Organization (1999) Report of a WHO consultation. Part 1: diagnosis and classification of diabetes mellitus; Department of noncommunicable disease surveillance; Geneva, WHO/NCD/NCS/99.2, pp. $1-66$.

14. Wild S, Roglic G, Green A, Sicree R, King H (2004) Global prevalence of diabetes: estimates for the year 2000 and projections for 2030. Diabetes Care 27: 1047-1053

15. Cheng D (2005) Prevalence, predisposition and prevention of type II diabetes. Nutr Metab 2: 29-39.
16. Islam MS, Loots DT (2009) Experimental rodent models of type 2 diabetes: A review. Methods Find Exp Pharmacol 31: 249-261.

17. Kunes J, Bazant J, Pour M, Waisser K, Slosarek M, et al. (2000) Quinazoline derivatives with antitubercular activity. IL Farmaco 55: 725-729.

18. Magnus NA, Confalone PN, Storace L, Patel M, Wood CC, et al. (2003) Teratogenic effects of a new quinazolinone derivative on the development of Balb/C mice fetuses on the days 9 and 11 of gestation. J Org Chem 68: 754 761

19. Jantova S, Urbancikova M, Maliar T, Mikuldsova M, Rauko P, et al. (2001) Biological activity of some 4-anilinoquinazolines: cytotoxic, genotoxic and antiprotease effects, induction of necrosis and changes of actin cytoskeleton. Neoplasm 48: 42-60.

20. Chern J, Tao P, Wang K, Gutcait A, Liu S, et al. (1998) Studies on quinazolines and 1,2,4-benzothiadiazine 1,1-dioxides 8.1, 2 Synthesis and pharmacological evaluation of tricyclic fused quinazolines and 1,2,4-benzothiadiazine 1,1-dioxides as potential a1-adrenoceptor antagonists. J Med Chem 41: 3128 3141.

21. Santegati A, Modica M, Santagati M, Cutuli VM, Mangano NG, et al. (2000) Synthesis and pharmacological screening of 1, 3, 4-thiadiazino [2,3-b] quinazoline derivatives. Pharmazie 55: 737-739.

22. Ram VJ, Farhanullah Tripathi BK, Srivastava AK (2003) Synthesis and antihyperglycemic activity of suitably functionalized $3 \mathrm{H}$-quinazolin-4-ones. Bioorg Med Chem 11: 2439-2444

23. Refaie FM, Esmat AY, Abdel Gawad SM, Ibrahim AM, Mohamed MA (2005) The antihyperlipidemic activities of $4(3 \mathrm{H})$ quinazolinone and two halogenated derivatives in rats. Lipids Health Dis 4: 22

24. Johnson WS, Woroch E, Mathews FG (1947) J Am Chem Soc 69: 566-570

25. Mariella RP (1947) Organic synthesis 4: 210.

26. Olfert ED, Cross BM, McWilliam AA (CCAC) (1993) Guide to the Care and Use of Experimental Animals. Vol 1, CCAC, Ottawa, Ontario, Canada, pp 1-298.

27. Afifi NA, Ramadan A, El-Kashoury EA, El-Banna HA (1994) Some pharmacological activities of essential oils of certain umbelliferous fruits. Vet Me J Giza 42: 85-92.

28. DR Lawrence (1964) Evaluation of drug activities and pharmacometrics Vol I. Academic Press, London.

29. Takada J, Fonseca-Alaniz MH, de Campos TB, Andreotti S, Campana AB, et al. (2008) Metabolic recovery of adipose tissue is associated with improvement in insulin resistance in a model of experimental diabetes. J Endocrinol 198 : $51-60$

30. Trinder $P$ (1969) Determination of blood glucose using an oxidase peroxidase system with a non-carcinogenic chromogen. J Clin Pathol 22: 158-161.

31. Marschner I, Bottermann P, Erhardt F, Linke R, Löffler G, et al (1974) Group experiments on the radioimmunological insulin determination. Horm Metab Res 6: 293-296.

32. Beyer J, Krause U, Cordes U (1979) C-peptide: its biogenesis, structure, determination and clinical significance. Giornate Ital Chem Clin 4: 9-22.

33. Seifter S, Dayton S, et al. (1950) The estimation of glycogen with anthrone reagent. Arch Biochem 25: 191-200.

34. Stalmans W, Hers $H$ (1975) The stimulation of liver phosphorylase b by AMP fluoride and phosphate. A technical note on the specific determination of the a and $b$ forms of liver glycogen phoshorylase. Eur J Biochem 54: 341-350. 
Citation: Ahmed OM, Hussein AM, Ahmed RR (2012) Antidiabetic and Antioxidant Effects of Newly Synthesized Pyrimido[1,6-A]Pyrimidine Derivatives in Neonatal Streptozotocin-Induced Diabetic Rats. Med chem 2: 020-028. doi:10.4172/2161-0444.1000108

35. Begum N, Moses SG, Shanmugasundaram KR (1978) Serum enzymes in human and experimental diabetes mellitus. Indian J Med Res 68: 774-784.

36. Brandstrup N, Kirk Je, Bruni C (1957) The hexokinase and phosphoglucoisomerase activities of aortic and pulmonary artery tissues in individuals of various ages. Gerontol 12: 166-171

37. Venugopala Rao A, Ramakrishan S (1975) Indirect assessment of hydroxymethyl glutaryl-CoA reductase (NADPH) activity in liver tissue. Clin Chem 21: 1523-1525.

38. Frings CS, Frenndley TW, Dunn RT, Queen CA (1972) Improved determination of total serum lipids by the sulfo-phosphoro-vanillin reaction. Clin Chem 18: 673-674.

39. Fossati $P$, Prencipe $L$ (1982) Serum triglycerides determined colorimetrically with an enzyme that produces hydrogen peroxide. Clin Chem 28: 2077-2080.

40. Allain CC, Poon LS, Chan CS, Richmond W, Fu PC (1974) Enzymatic determination of total serum cholesterol. Clin Chem 20: 470-475.

41. Burnstein M, Selvenick HR, Morfin R (1970) Rapid method for isolation of lipoprotein from human serum by precipitaion with polyanions. J Lipid Res 11: 583-595

42. Friedewald WT, Levy RI, Fredrickson DS (1972) Estimation of the concentration of low-density lipoprotein in plasma, without use of the preparative ultracentrifuge. Clin Chem 18: 499-502.

43. Nobert WT (1995) In Clinical Guide to Laboratory tests. $3^{\text {rd }}$ edition, WB Saunders Company, Philadelphia.

44. Koster JF, Biermond P, Swaak AJ (1986) Intracellular and extracellular sulphhydryl levels in rheumatoid arthritis. Ann Rheum Dis 45: 44-46.

45. Beutler E, Duron O, Kelly BM (1963) Improved method for the determination of blood glutathione. J Lab Clin Med 61: 882-888.

46. Preuss HG, Jarrel ST, Scheckenbach R, Lieberman S, Anderson RA (1998) Comparative Effects of Chromium, Vanadium and Gymnema Sylvestre on Sugar-Induced Blood Pressure Elevations in SHR. J Am Coll Nutr 17: 116-123.

47. Goldberg DM, Spooner RJ (1983) In Methods of enzymatic analysis: Bergmeyer, HV, 3rd edition, Verlag Chemie, Deerfield, Beach, FI Vol. 3, pp: 258-265.

48. Pinto RE, Bartley W (1989) The effect of age and sex on glutathione reductase and glutathione peroxidase activities and on an aerobic glutathione oxidation in rat liver homogenates. Biochem J 112: 109-115.

49. Mannervik B, Guthenberg C (1981) Glutathioine transferase (human placenta). Methods Enzymol 77: 231-235

50. Cohen G, Dembiec D, Marcus J (1970) Measurement of catalase activity in tissue extract. Anal Biochem 34: 30-38.

51. Bancroft JD, Stevens A (1992) In Theory and Practice of histological technique 2nd edition; Churchill Livingstone, pp 374-375.

52. Rao M, Blane K, Zonneberg M (1985) PC-STAT program, Version 1A (C). University of Georgia, USA

53. Hirota K, Kitade Y, Sajika H, Maki Y (1984) A Facile Synthesis of 7-Substituted Pyrimido[4,5-d]-Pyrimidine-2,4-diones. Synthesis 1984: 589-590.

54. Hirota K, Sajiki H, Kitade Y, Maki Y (1990) Novel ring transformations of 5-cyanouracils into 2-thiocytosines, 2,4-diaminopyrimidines, and pyrimido[4,5-d] pyrimidines by the reaction with thioureas and guanidines. J Chem Soc Perkin Trans 1: 123-128.

55. Srvastava SW, Haq W, Chauhan PM (1999) Solid phase synthesis of structurally diverse pyrimido[4,5-d]pyrimidines for the potential use in combinatorial chemistry. Bioorg Med Chem Lett 9: 965-966.

56. Elgemeie GH, Ali HA (2002) Potential purine analogue antagonist: Synthesis of novel cycloalkane ring-fused pyrazolo[1,5-a]pyrimidines. Synth Commun 32 253-264.

57. Hussein AM, Ahmed SA, Hozayen WG, El-Ghandour AH, Abdelhamid AO (2007) Synthesis of some pyrazolopyrimidines as purine analogues. J Heterocyclic Chem 44: 803-810.

58. Hussein AM (2012) Novel Synthesis of Some New Pyrimido[1,6-a]pyrimidine and Pyrazolo[1,5-a]pyrimidine Derivatives. J Heterocyclic Chem: First published online.
59. Arulmozhi DK, Veeranjaneyulu A, Bodhankar SL (2004) Neonatal streptozotocin-induced rat model of Type 2 diabetes mellitus: A glance. Ind J Pharmacol 36: 217-221.

60. Fantus IG, Chayoth R, O'Dea L, Marliss EB, Yale J, et al. (1987) Insulin binding and glucose transport in adipocytes in neonatal streptozocin-injected rat model of diabetes mellitus. Diabetes 36: 654-660.

61. Murali B, Goyal RK (2001) Improvement in insulin sensitivity by losartan in noninsulin-dependent diabetic (NIDDM) rats. Pharmacol Res 44: 385-389

62. Ryu J, Kim D, Lee T, Kang Y, Yoon S, et al. (2003) The role of free radical in the pathogenesis of impotence in streptozotocin-induced diabetic rats. Yonse Medical J 44: 236-241.

63. Pari L, Ashokkumar N (2005) Effect of N-benzoyl-D-phenylalanine, a new potential oral antidiabetic agent, in neonatal streptozotocin-induced diabetes in rats. Pharmacol Rep 57: 498-503.

64. Alper G, Olukman M, Irer S, Cağlayan O, Duman E, et al. (2006) Vitamin E and $\mathrm{C}$ improve diabetic vasculature, but worsen endothelial dysfunction in diabetes. Diabetes Metab Res Rev 22: 190-197.

65. Takada J, Machado MA, Peres SB, Brito LC, Borges-Silva CN, et al. (2007) Neonatal streptozotocin-induced diabetes mellitus: a model of insulin resistance associated with loss of adipose mass. Metablism 56: 977-984.

66. Dewanjee S, Maiti A, Das AK, Mandal SC, Dey SP (2009) Swietenine: a potential oral hypoglycemic from Swietenia macrophylla seed. Fitoterapia 80 249-251.

67. Masiello $P$ (2006) Animal models of type 2 diabetes with reduced pancreatic beta-cell mass. Int J Biochem Cell Biol 38: 873-893.

68. Grover JK, Vats V, Rathi SS (2000) Anti-hyperglycemic effect of Eugenia jambolona and Tinospora cordifolia in experimental diabetes and their effects on key metabolic enzymes involved in carbohydrate metabolism. J Ethnopharmacol 73: 461-470

69. Mukherjee SS, Murthi PS, Mukherjee SK (1976) Studies on the mechanism of centpiperalone-induced hypoglycemia. Acta Diabetol Lat 13: 8-19.

70. O'Meara NM, Devery RA, Owens D, Collins PB, Jhonson AH, et al. (1990) Cholesterol metabolism in alloxan-induced diabetic rabbits. Diabetes 39: 626633.

71. Shimada M, Shimano H, Gotoda T, Yamamoto K, Kawamura M, et al. (1993) Overexpression of human lipoprotein lipase in transgenic mice: resistance to diet-induced hypertriglyceridemia and hypercholesterolemia. J Biol Chem 208 : 17924-17929.

72. Ugawa T, Kakuta H, Moritani H, Inagaki O (2002) Effect of YM-53601, a nove squalene synthase inhibitor, on the clearance rate of plasma LDL and VLDL in hamsters. Br J Pharmacol 137: 561-569.

73. Mullarkey CJ, Edelstein D, Brownlee M (1990) Free radical generation by early glycation products: a mechanism for accelerated atherogenesis in diabetes. Biochem Biophys Res Commun 173: 932-939. 